\title{
FACIES AND DIAGENESIS OF TABALAR AND TENDEHANTU CARBONATE FORMATION IN MANGKALIHAT PENINSULA AREA: AN OUTCROP PRELIMINARY STUDY TO OLIGOCENE - MIOCENE RESERVOIR CANDIDATE PROSPECT
}

\section{FASIES DAN DIAGENESIS FORMASI TABALAR DAN TENDEHANTU DI TANJUNG MANGKALIHAT: STUDI AWAL BERDASARKAN SINGKAPAN UNTUK KEPROSPEKAN KANDIDAT RESERVOIR BERUMUR OLIGOSEN - MIOSEN}

By:

\author{
Risman Adhitiya ${ }^{1 *}$, Merza Media Adeyosfi', Syahreza S Angkasa', Felix Sihombing', \\ ${ }^{1}$ Faculty of Geology,University Padjadjaran \\ ${ }^{2}$ Departement of Geological Engineering, Bandung Institute of Teknology
}

\begin{abstract}
Mangkalihat peninsula is located between Kutai and Tarakan basins, which known as two Hydro Carbon (HC) Prolific basins in Eastern Borneo. The petroleoum system in this area is poorly known because of the different system between Kutai and Tarakan Basin. The field study is focusing in the eastern part of Mangkalihat Peninsula, where The Tabalar and Tendehantu Formation are exposed.
\end{abstract}

The data compilation is from outcrop, thin section and plug sample which permeability and porosity values were measured by Klickenberg method. Outcrop analysis showed that Tendehantu Formation can be divided into two lithofacies, whileTabalar Formation has only one lithofacies. The petrographic thin section analysis showed three microfacies from the two formations.

Pore destruction caused by diagenesis can de indicated with the presence of bladed and equant cement in vuggy pores, while the diagenetical development of porosity is marked by the microfracturing that was assumed to be formed by compaction and deep burial and matrix dissolution in some of the samples.

Petrography and plug sample data integration shows the quality value of those carbonate rock as a reservoir from the permeability and porosity parameter. Based on the microfacies grouping showed in three microfacies, the porosity value is $5.26-17.32 \%$ (tight to good), and permeability value is $0.041-7.27 \mathrm{mD}$ (fair - poor). The carbonate rock quality is influenced by the whole diagenetic processes that happened in each lithofacies.

Keywords : facies, diagenesis, Tabalar Formation, Tendehantu Formation, carbonate

\section{SARI}

Tanjung Mangkalihat terletak di antara Cekungan Tarakan dan Kutai, yang dikenal sebagai 2 cekungan berpotensi hidrokarbon di bagian timur Kalimantan. Perbedaan sistem antara kedua cekungan tersebut menyebabkan sistem perminyakan di daerah ini tidak diketahui dengan baik. Studi lapangan difokuskan pada singkapan-singkapan Formasi Tabalar dan Formasi Tendehantu yang tersusun oleh batuan karbonat di bagian timurtanjung Mangkalihat.

Kompilasi data didapat dari singkapan, sayatan tipis dan conto batuan yang diukur angka porositas dan permeabilitasnya dengan Metode Klickenberg. Analisis singkapan menunjukkan bahwa Formasi Tendehantu tersusun oleh dua litofasies, sedangkan Formasi Tabalar hanya oleh satu litofasies. Petrografi sayatan tipis menunjukkan adanya tiga mikrofasies dari kedua formasi ini. 
Kerusakan pada pori-pori batuan akibat proses diagenesis terlihat dari adanya struktur bilah pada semen, sedangkan perkembangan diagenesis pada porositas ditandai oleh struktur mikrofraktur yang diasumsikan terbentuk oleh proses kompaksi akibat sedimentasi cukup dalam dan pelarutan matriks pada beberapa sampel.

Integrasi hasil analisis petrografi dan sampel batuan menunjukkan kualitas batuan karbonat dari parameter permeabilitas dan porositas batuan. Berdasarkan analisis dari tiga mikrofasies, didapat nilai porositas berkisar antara 5,26-17,32\% (rendah - baik) dan permeabilitas antara 0,041-7,27 mD (sedang-buruk). Kualitas batuan karbonat dipengaruhi oleh proses diagenetik yang menyeluruh pada setiap litofasies.

Kata kunci : fasies, diagenesis, Formasi Tabalar, Formasi Tendehantu, karbonat

\section{INTRODUCTION}

Mangkalihat peninsula is located between Kutai and Tarakan basins, which known as two HC Prolific basin in Eastern Borneo. The petroleum system is poorly known because of the different system between Kutai and Tarakan (Figure 1). Field study is focusing in the eastern part of Mangkalihat Peninsula, where The Tabalar and Tendehantu are exposed. The location was chosen as a key to conduct the tectonic understanding related to petroleum system in this area. The study is a compilation of field study data for preliminary reservoir prediction based on outcrop data, petrographic thin section analysis and plug sample porosity, permeability estimation to predict the reservoir candidate.

\section{METHODOLOGY}

This study is integrated from the result from field work, there are 29 spots of outcrop station for analysis in $10 \mathrm{~km}^{2}$ area in Eastern Mangkalihat. The outcrop samples furthermore were selected and grouped by the lithofacies based on outcrop analysis. The representing samples from some facies of Tabalar and Tendehantu Formations, furthermore were made as plug sample to porosity and permeability analysis for reservoir candidate prospecting. For carbonates facies and microfacies analysis, this study used petrographic observation to understand the porosity, mineralogy, and carbonate fragment distribution. This analysis was also used in order to interpret the depositional environtment and diagenetic history and feature (Figure 2).

\section{REGIONAL GEOLOGY \& STRATIGRAPHY}

Mangkalihat Peninsula located in eastern part of Borneo, physiographically this is a highland which separates Kutai and Tarakan basins into southern and northern area respectively. Tectonically, Mangkalihat is a microcontinent from Northern Gondwana which was drifted to equator in Late Jurassic, as an impact of the opening of Cenotethys Ocean (Metcalfe, 1996). The other well known name of this microcontinent is Paternoster Terrain. This Terrain was continually acreted to early Sunda Terrain in their Southeastern segment (Continental core of Schwaner Microplate) in 150-60 Ma (Satyana, 2003) (Figure 3).

This acretion is marked by the presence of Adio Suture or Suikerbrood High in Western Mangkalihat. The acretion that was happened in western part of Mangkalihat during the Early Tertiary implicated as sediment fill to the eastern part along the transgressive phase during the time.

Mangkalihat platform during Paleogene was dominantly filled by neritic - paludal sedimentary product, and in Neogene was dominantly filled by regressive phase sediment.

Regional stratigraphy of this study area is subdivided into four formations, from older to younger during Late Oligocene to Pliocene interval. They are Tabalar Formation, which is dominated by white - grey limestone, and Tendehantu Formation which consists of coraline limestone, with white - yellow colour, Lembak Formation which is dominated by marl and limestone and Golok Formation which is dominated by marl with interuption of claystone and marl-limestone 


\section{MAKALAH ILMIAH}

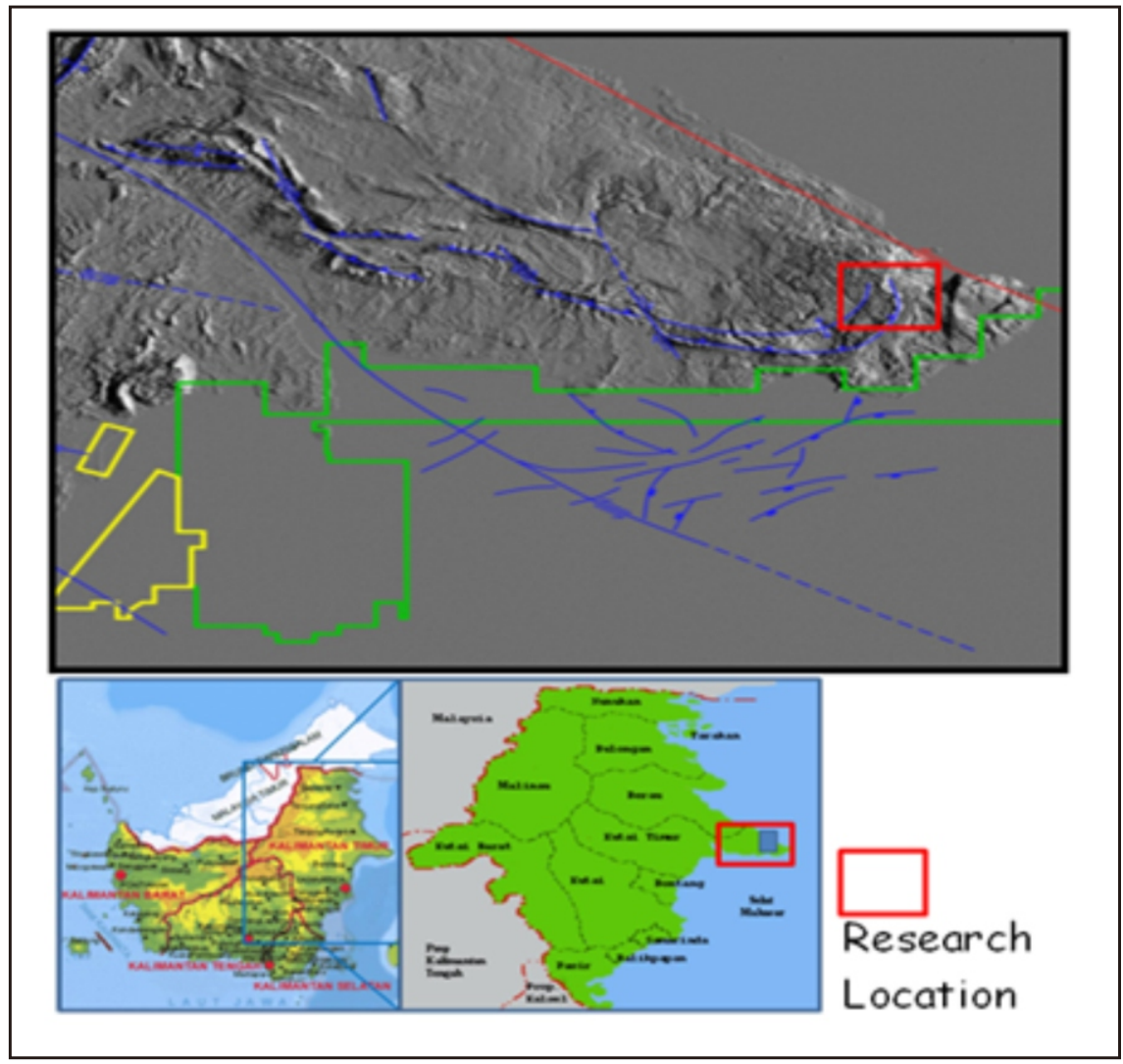

Figure 1 - Location index of the research area

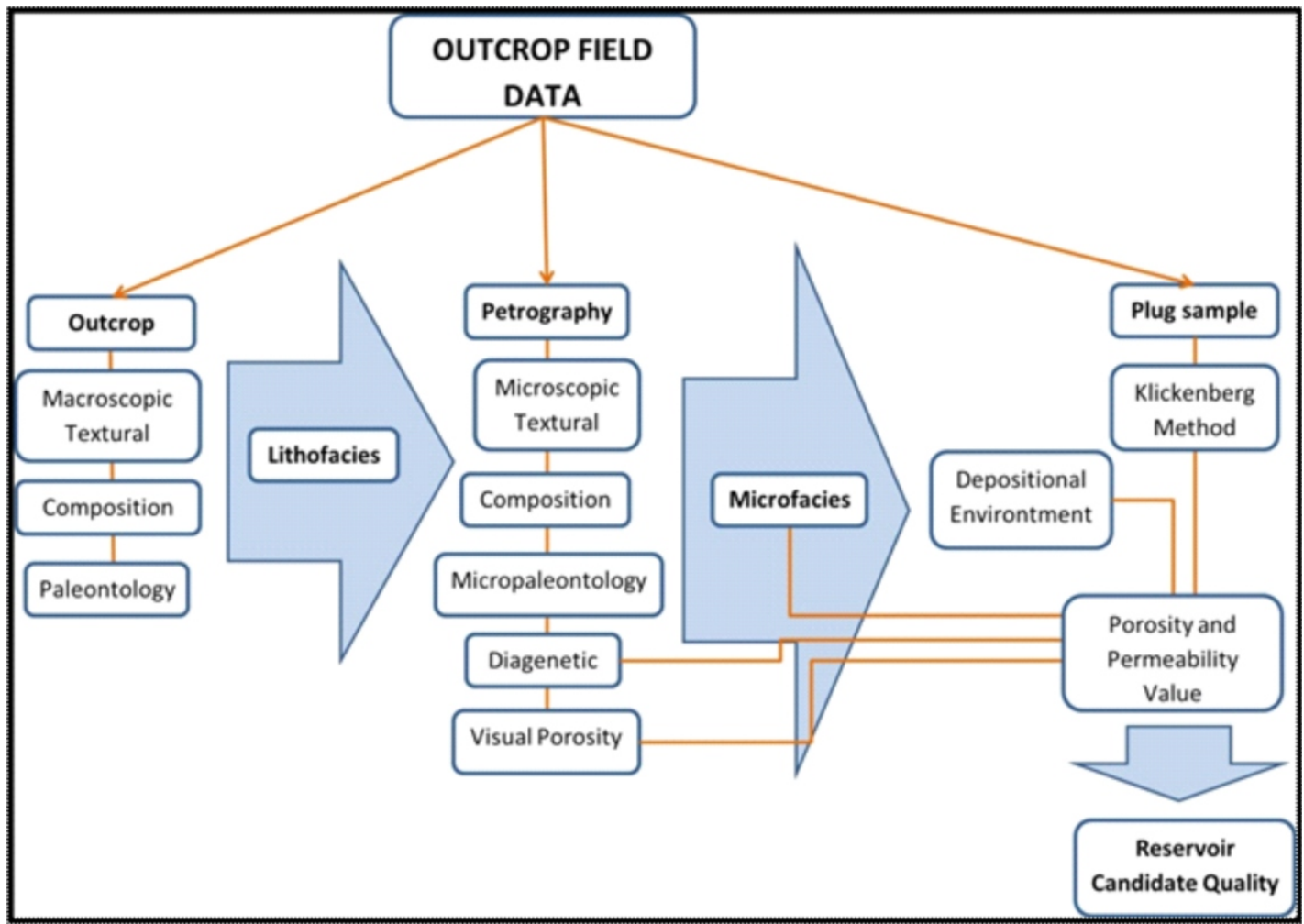

Figure 2 - Research workflow. 


\section{MAKALAH ILMIAH}

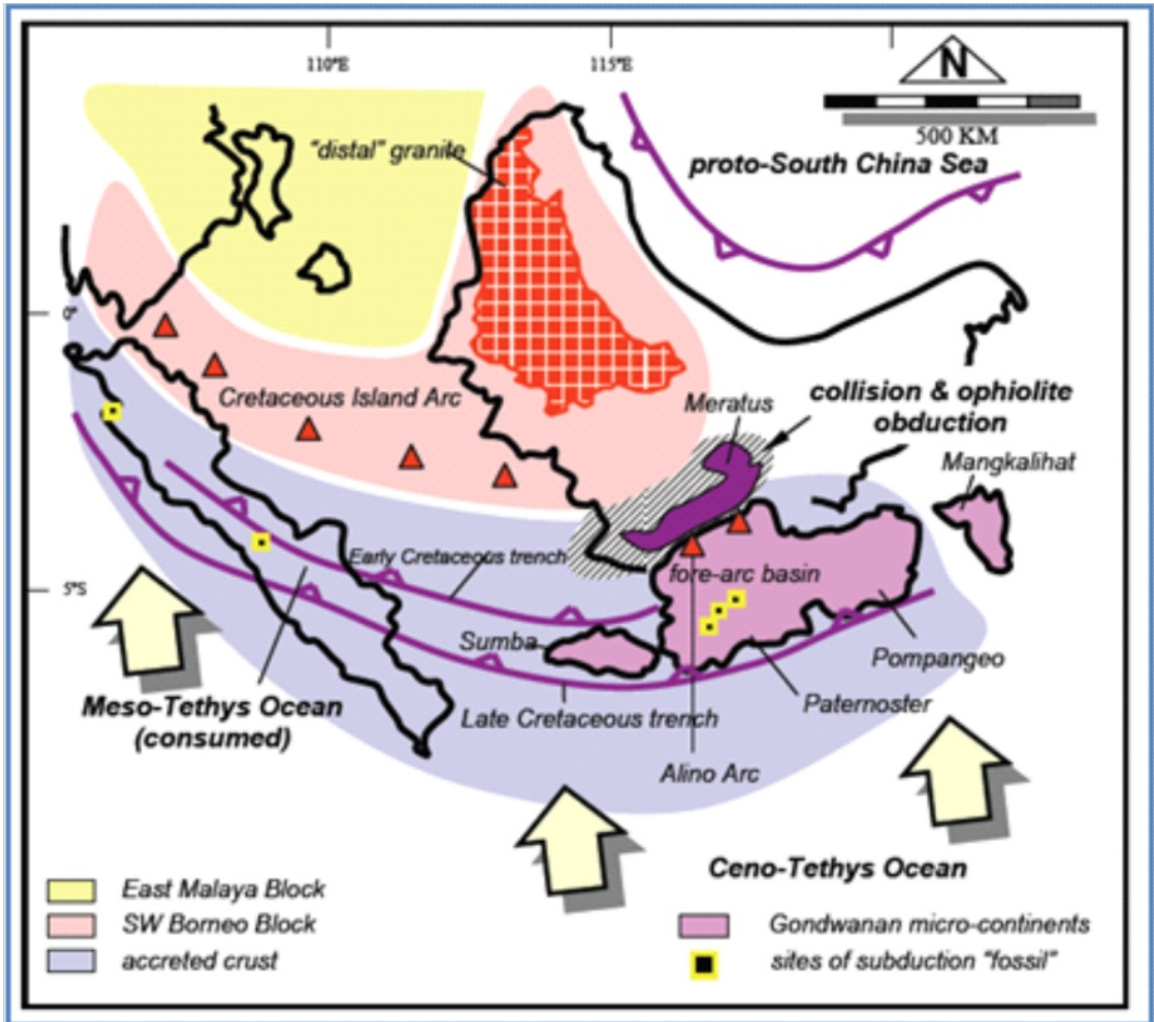

Figure 3 - Tectonic scheme of the Mangkalihat in Cretaceous - Paleogen (Satyana, 2003)

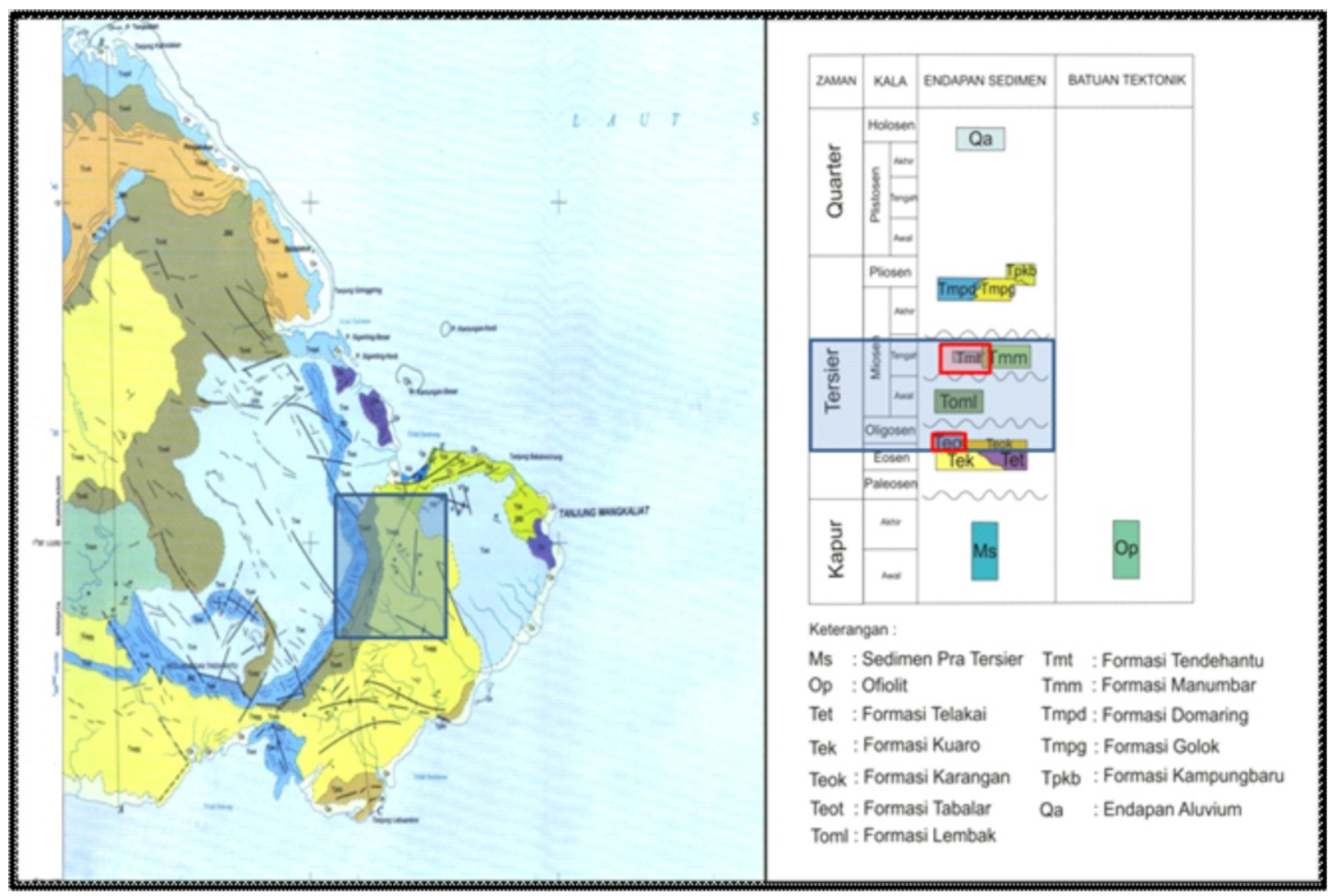

Figure 4 - Regional Geological map and stratigraphical colum of research area, (Blue block shows interval of study) (Djamal et al., 1995) 


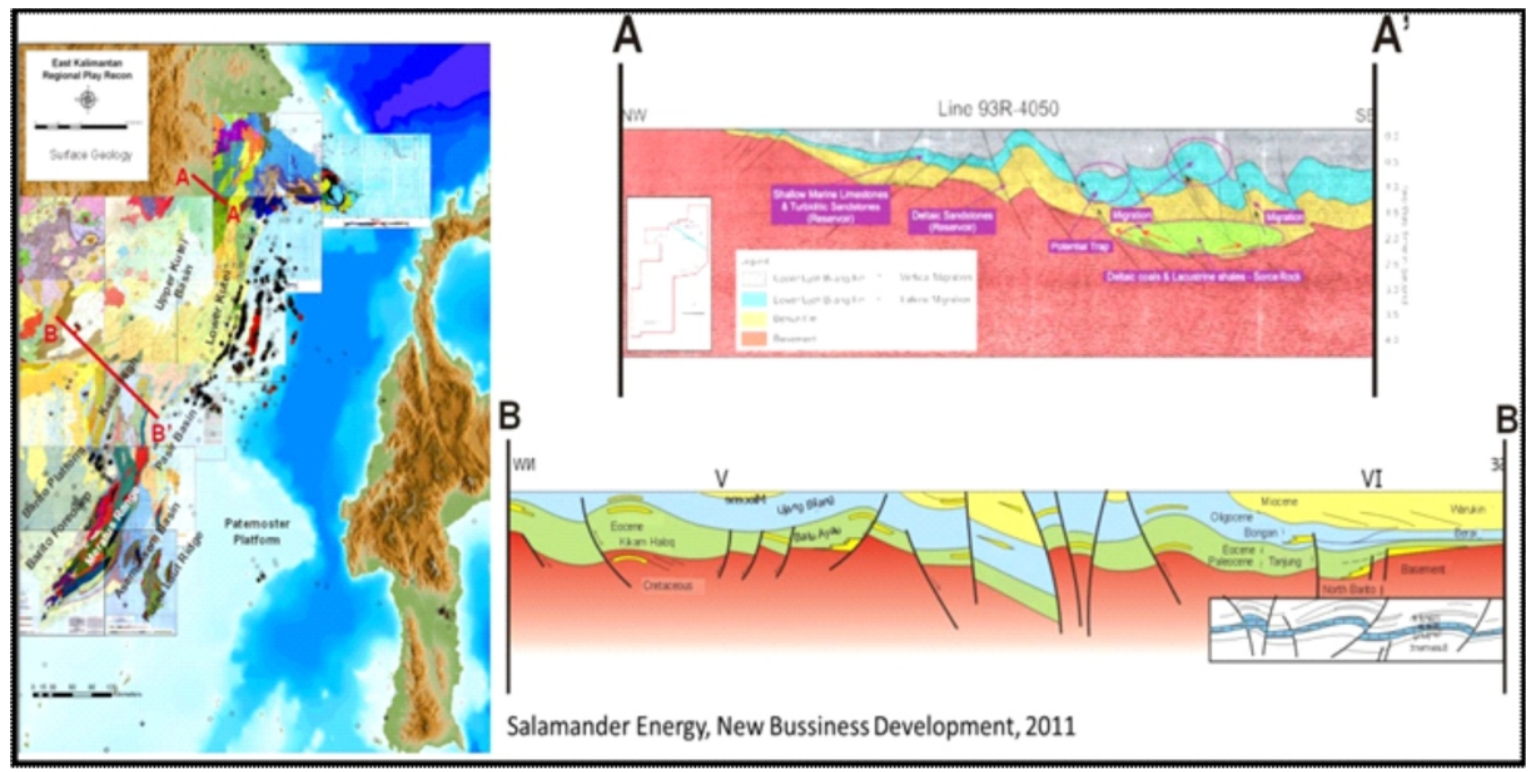

Figure 5 - Play mechanism intersection from regional petroleum system in research area.

with molusca. The focus of stratigraphical segment in this study is in Tendehantu and Tabalar Formations.

\section{PETROLEUM SYSTEM}

The petroleum system analogue was adopted from comparison with the play mechanism in East Kalimantan (Figure 5 ). The potential source rock is from Paleocene - Eocene segment, consists of deltaic coal and lacustrine of Kutai Basin. The turbidite sandstone and shallow marine deposit also play as reservoir potential in Southern Kutai Basin, that were developed during Eocene Oligocene. In this study, the Oligocene Miocene sediments that play as the main target reservoirs are the Tendehantu and Tabalar Formation. The analogue of trapping mechanism in the research area is the present marine segment such as Golok Formation (Figure 4). The migration mechanism can be interpreted by cross section (Figure 5) of an inverted regime during Miocene. This analogue can be reflected in the study area as when Sangkulirang and Maratua Faults were active and developed during Miocene and probably to Recent. The migration mechanism can openly transport the mature hydrocarbon to be trapped in the Eocene Miocene Reservoir in this study area.

\section{CARBONATE FACIES ANALYSIS}

Carbonate facies analysis was interpreted based on lithology, texture, composition and fossil content, that observed in field description. Based on that examination Tabalar and Tendehantu Formation were divided into 3 lithofacieses. Further analysis, especially for microfacies determination, was interpreted based on thin section texture, composition, fossil content and diagenetic feature.

Tabalar Formation has one lithofacies that can be determined as packestone wackestone lithofacies (Table 1). This lithofacies is dispersed in the western part of research area (Figure 6), and spreads from North to South trend. The lithofacies has characters of massive body with no bedding feature, white colour, and poor - medium sorted fragment consists of branching and platy coraline as well as containing bivalve shells. The porosity that can be observed is moldic and vuggy as the product of intense dissolution (Figure 11). Petrographical analysis showed that it is generally poorly sorted with grain from $0.2-4 \mathrm{~mm}$ range, medium abrated with float and point contact. The dominant fragments are bryozoan, larger forams and coraline fragment.

Based on dominant fragment marker, on petrographical analysis, this lithofacies can be divided into 2 microfacies clusters namely the Larger Forams - Coraline Wackestone 
and the Bryozoan - Coraline Packestone Grainstone microfacies.

The Tendehantu Formation is divided into 2 lithofacies namely wackestone packestone and packstone - grainstone lithofacies.

The wackestone - packestone lithofacies in Tendehantu Formation, has 5 observation stations, which showed poorly sorted with closed packing, the grains mainly from $0.2-5 \mathrm{~mm}$ range, with moderately abrated and showed point and float contact (Figure 10). Petrographical analysis showed that matrix content is ranging from $26-41 \%$ and pore visual from $7-15 \%$, the dominant grain is larger forams. Further analysis for this lithofacies based on petrographical analysis, showed that it can be clustered into 2 microfacies clusters, those are Larger Forams Packestone and Indeterminated Bioclast - Algae Packestone. This microfacies clustering will become a guidance for determining the quality of reservoir candidate.

The packestone - grainstone lithofacies in Tendehantu Formation generally showed a poorly sorted feature in microscopic, with $0.2-4 \mathrm{~mm}$ grain and moderately abrated, with point and float contact matrix range from $34-45 \%$ (Figure 10). From further petrographical analysis the lithofacies has 3 microfacieses namely Indeterminated Bioclast Packestone, Larger Forams Bryozoan Packestone and Larger Forams Grainstone.

\section{RESUME OF DIAGENESIS}

Based on peterographic analysis, the diagenetic processes observed in Tabalar and Tendehantu Formations include as follows:

\section{Microbial Micritization}

This process was a result of drilling activity in skeletal grain by endolithic algae, fungi and bacteria forming holes and filled with fine sediment or cement. This activity is marked by the presence of micrite envelope. If the hole is not filled up by fine sediment, the hole will be corroded and the moldic porosity formed. Micritization is an important process in both stagnant and active marine phreatic zones (Longman, 1982).

\section{Dissolution}

Dissolution occured when the diagenetic environment were different, the minerals became unstable and dissolved easily and then transformed into more stable minerals in a new environment. Dissolution intensively happened in several microfacieses in Tabalar Formation, produced secondary porosity as moldic and vuggy (Figure 10 - B). Dissolution occurred as well in freshwater vadose or freshwater phreatic environments (Longman, 1982).

\section{Cementation}

This processes occured when the pores were fluid supersaturated and there was no kinetic factor hampering the cement precipitation. Based on the analysis in Tabalar and Tendehantu there are three kinds of cement that can observed: fibrous, blocky and bladed. Bladed and blocky were dominantly observed in Tabalar Formation. Bladed and fibrous cement showed marine phreatic environment, while blocky formed in meteoric phreatic (Figure 11).

\section{Neomorphism}

Neomorphism is a diagenetic product that has larger size inverse micrite recrystalization. The formed crystal showed more clouded colour than spar cement and microspar. Neomorphism occured in meteoric phreatic environment and present dominantly in both formations.

\section{Compaction}

Mechanical and chemical compaction occur in deep burial environment, caused by pressure and fluid involved. In Tabalar Formation compaction feature showed grain fractures and stylolites. This diagenetic processes gave a huge effect to reduce the pore value.

Based on the processes explained above, it can be summarized that the sequence of diagenetic processes in Tabalar and Tendehantu Formations are:

First stage diagenesis occured in marine phreatic and fresh water phreatic zone characterized by the occurrence ofmicritization, fibrous and equant cement.

Second stage is burial environment, shown by mechanical compaction and 
Table 1 Data Recapitulation

\begin{tabular}{|c|c|c|c|c|c|}
\hline \multicolumn{3}{|c|}{ Tendehantu Formation } & \multicolumn{3}{|c|}{ Tabalar Formation } \\
\hline \multirow{2}{*}{\multicolumn{3}{|c|}{$\begin{array}{c}\text { Packestone-Grainstone } \\
\text { Lithofacies }\end{array}$}} & \multirow{2}{*}{\multicolumn{3}{|c|}{$\begin{array}{c}\text { Wackestone- } \\
\text { Packestone Lithofacies }\end{array}$}} \\
\hline & & & & & \\
\hline Outcrop & TS & Plug & Outcrop & TS & Plug \\
\hline RA 2-4 & & & RA 13-2 & & \\
\hline RA 2-2 & & & RA13-3 & & \\
\hline RA 2-9 & & & RA 13-4 & & \\
\hline \multicolumn{3}{|c|}{$\begin{array}{c}\text { Wackestone- } \\
\text { Packestone Lithofacies }\end{array}$} & RA 13-5 & & \\
\hline $\begin{array}{c}\text { RA } 16 \mathrm{~T} \\
-5\end{array}$ & & & RA 13-6 & & \\
\hline RA $16 \mathrm{~T}-3$ & & & RA13-8 & & \\
\hline RA 2-8 & & & RA 14-1 & & \\
\hline RA 2-5 & & & RA 14-2 & & \\
\hline RA 7-1 & & & RA 14-5 & & \\
\hline & & & & & \\
\hline & & & & & \\
\hline & & & & & \\
\hline & & & & & \\
\hline
\end{tabular}

chemical compaction. This stage is marked by point and long contact,as well as stylolite forming.

Third stage occured in meteoric phreatic, shown by blocky cement, neomorphism and dissolution, This stage was dominantly occured in Tabalar Formation

The tectonic processes that happened to these two research formations caused them to uplift and be located near to the surface position. The diagenetic stage was then changed into meteoric vadose. During this time, when the contact beetwen carbonate formations and meteoric water was intense, vug and other secondary porosity were formed. Tabalar Formation had more intense processes than Tendehantu Formation in this stage.

\section{CARBONATE RESERVOIR CANDIDATE QUALITY}

The carbonate reservoir quality prediction was taken from microfacies distribution based on the plugs of outcrop samples that were analyzed with routine core analysis method. For Tendehantu Formation there is the Indeterminated Bioclast - Bryozoan - Larger Forams in
Packestone - Grainstone microfacies. The quality of this microfacies is $8-12 \%$ for visual porosity and dominated by the moldic, vugs and fracture porosity. The plug outcrop porosity is $7.51-10.65 \%$ with horizontal permeability value between $0.014-15.1 \mathrm{mD}$. Based on those values this microfacies in general has poor - good quality as a reservoir. The crossplot sample data showed bad correlation between the porosity and the permeability values in this microfacies. Then it can be assumed that diagenesis factor was involved to decrease the microfacies quality, as like tight cementation that reach 5-7\%.

The Tabalar Formation has two microfacies clusters. Those are Larger Forams - Coraline Wackestone and Bryozoan - Coraline Packestone Grainstone.

The Larger Forams - Coraline Wackestone generally can be classified as a good quality reservoir based on the visual porosity which reachs $14 \%$. This porosity is dominated by moldic, intercrystaline and vug (Figure 11). Two plugs of outcrop were analyzed and showed the porosity and permeability values are $16.74-17.32 \%$ and $3.985-7.278 \mathrm{mD}$ respectively which then classified into fair reservoir classification (Koesoemadinata, 1980). Crossplot diagram from the data showed that the permeability and porosity has relative correlation, which 


\section{MAKALAH ILMIAH}

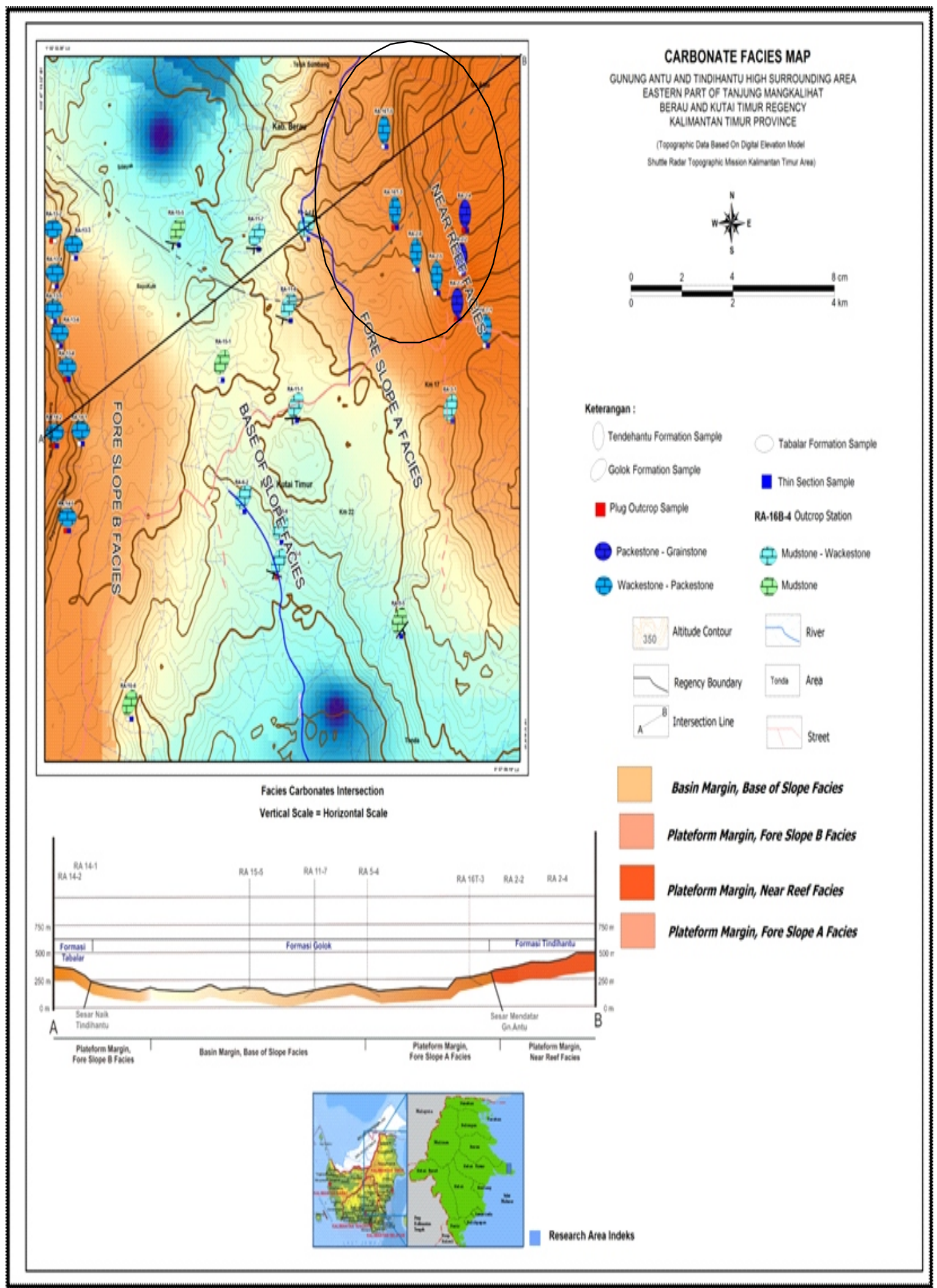

Figure 6 - Carbonates facies map 


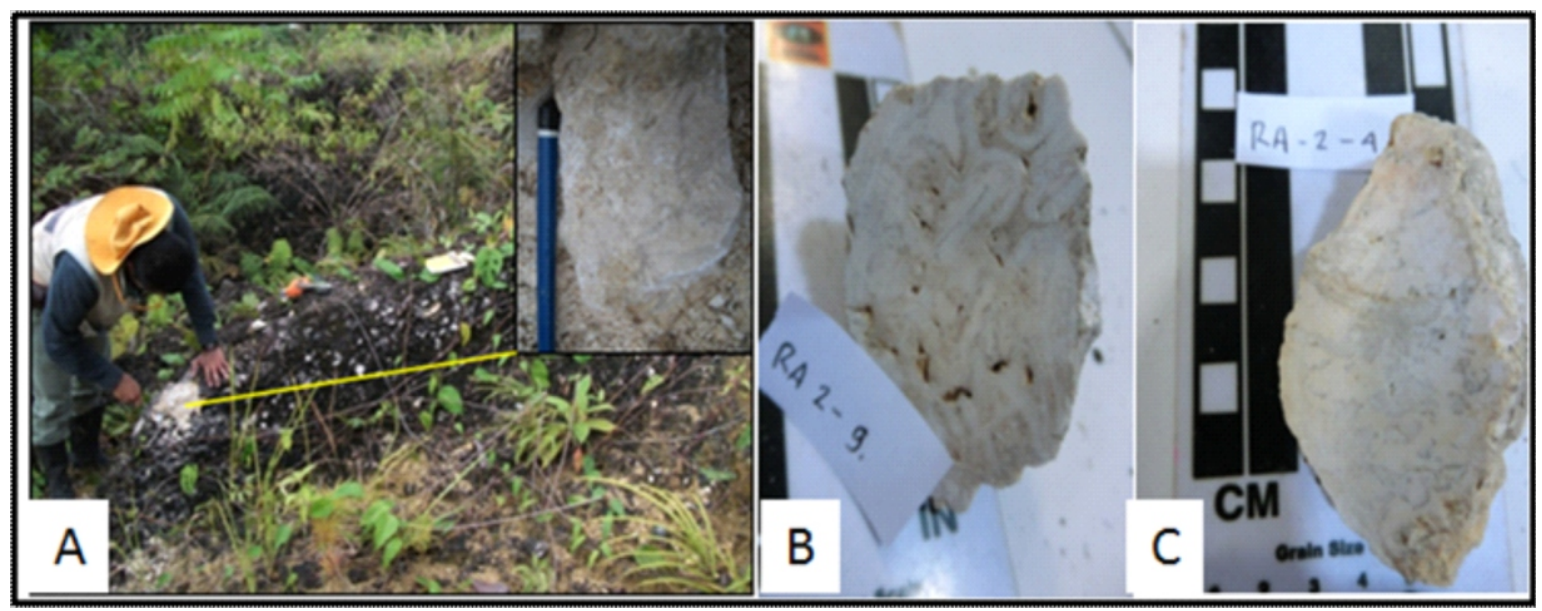

Figure 7. Tendehantu Formation outcrop represents packestone - grainstone lithofacies

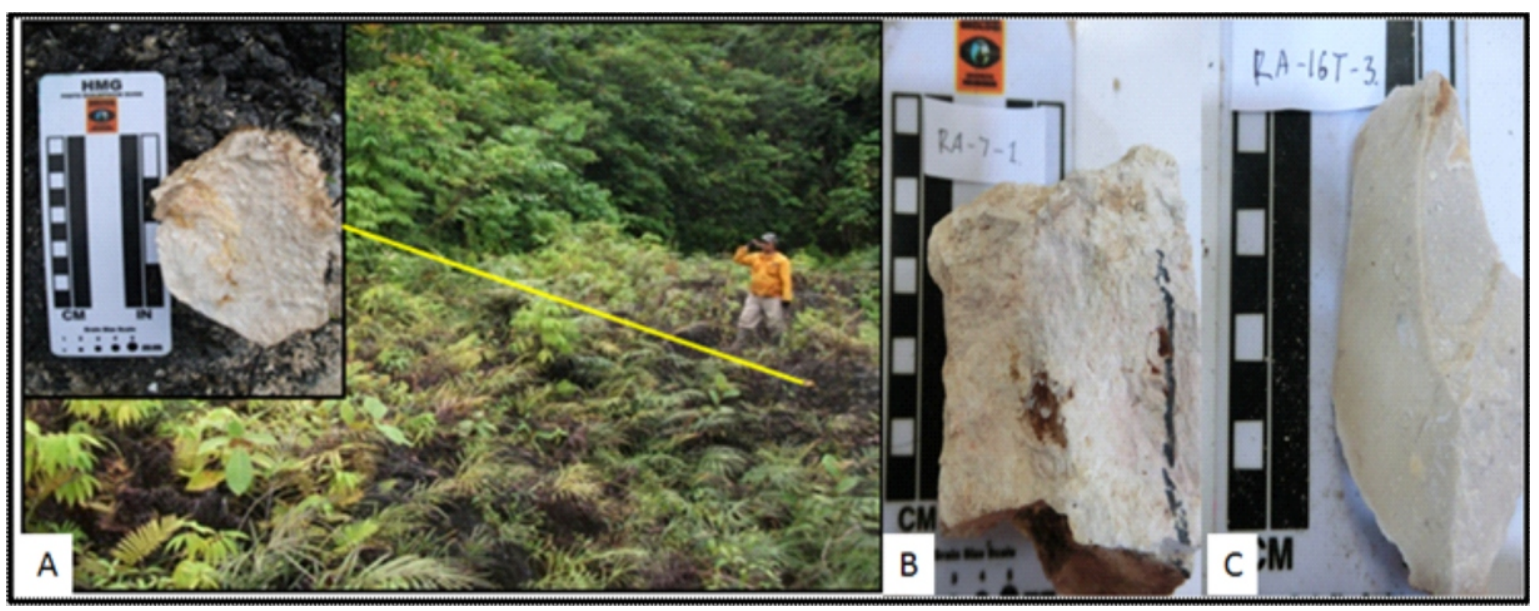

Figure 8 - Wackestone - packestone lithofacies in Tendehantu Formation

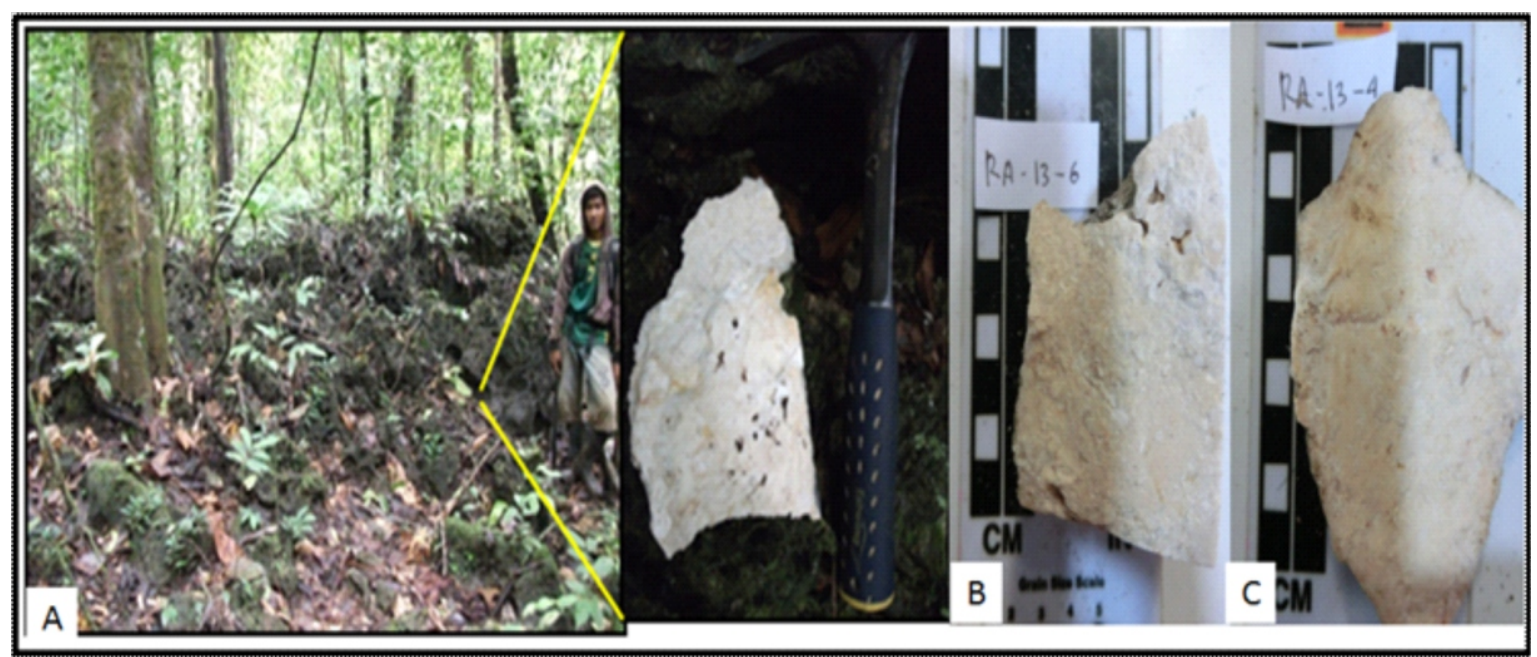

Figure 9. Wackestone - packestone lithofacies in Tabalar Formation 


\section{MAKALAH ILMIAH}
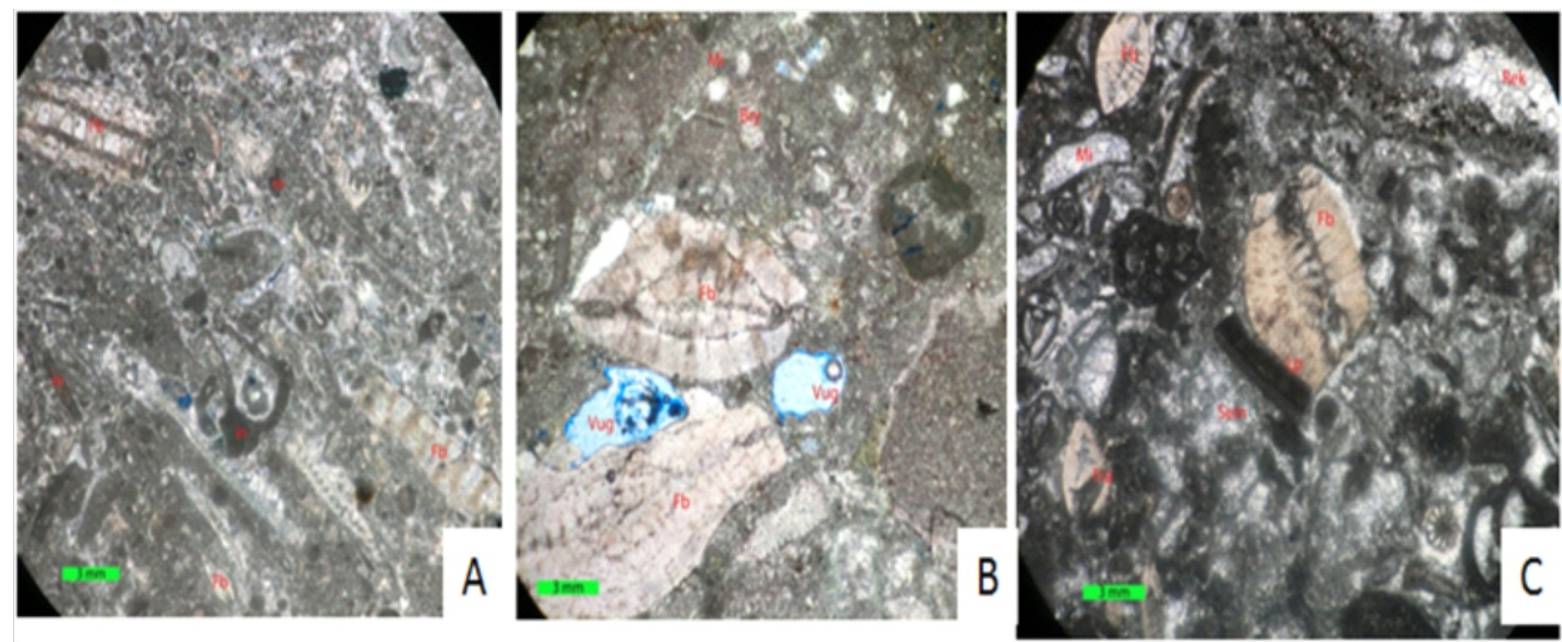

Figure 10 - Three thin section photographs from Tendehantu Formation with 40x lens magnification, RA 24 (A) Cross polarization; Indeterminated bioclast packestone RA 2 (B) plane polarization; Larger Forams -Bryozoan Packestone, RA 16 T-3 (C) Cross polarization; Larger Forams Packestone. (Fb : Larger Forams, Lp : Long Contact, Mi: Micritization, Rek: Recrystalization, Fra : Fracture, Bry: Bryozoan, Vug: Vuggy Pore)
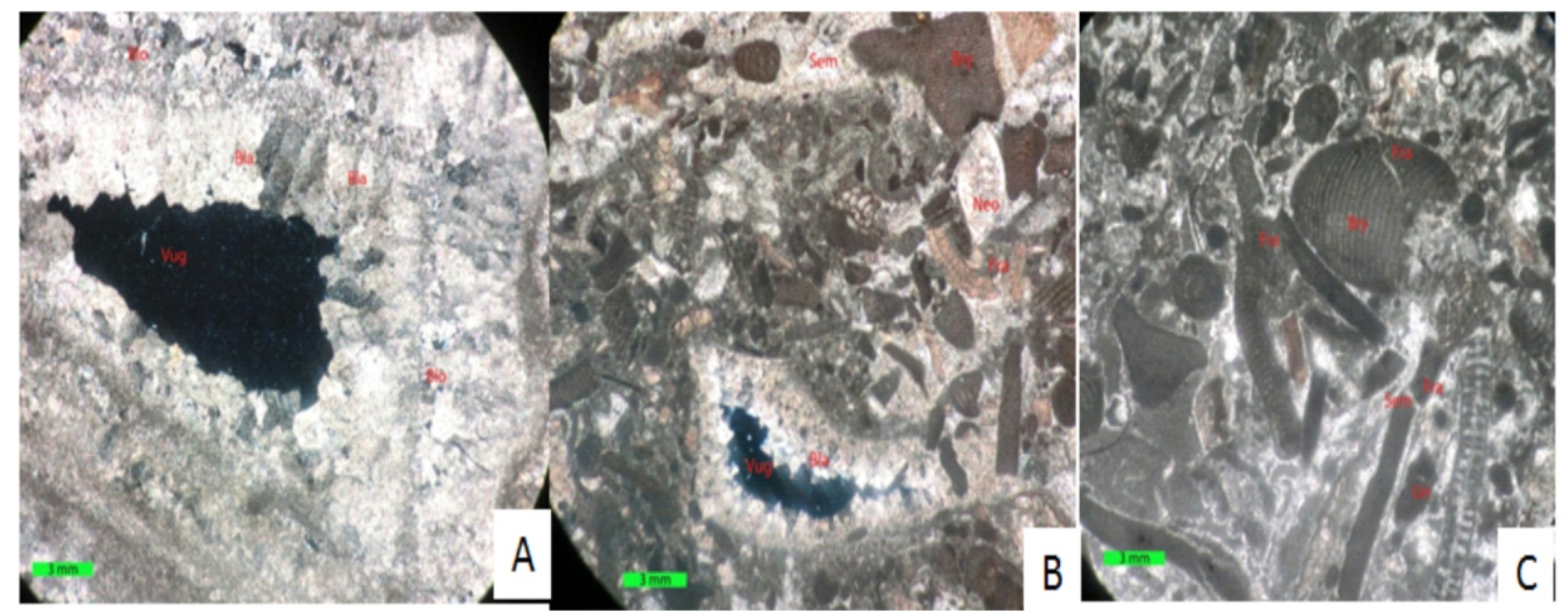

Figure 11 - Three thin section photographs from Tabalar Formation with 40x lens magnification, RA $13-3$ (A) Cross polarization; Larger Forams Coraline Wackestone, RA 13-6 (B) cross polarization; Bryozoan - Coraline Packestone - Grainstone, RA 13 - 4 (C) Bryozoan - Coraline Packestone - Grainstone. (Red assign : Blo : Blockycement, Bla: Bladed Cement, Vug: Vuggy Pore)

means that the increasing porosity can be followed by the increase of permeability as well. This good relationship between permeability and porosity can be interpreted as the result of dissolution process of diagenesis.

Bryozoan - Coraline Packestone Grainstone in Tendehantu Formation is the last microfacies cluster. Two outcrop sample plugs RA 14-5 and RA 14-2 were analyzed and showed $5.26-8.51 \%$ porosity and $0.052-0.039 \mathrm{mD}$ for horizontal permeability. The visual porosity value is between $9-17 \%$, dominated by moldic, intercrystaline and vug porosity. The permeability and porosity crossplot data showed that the data has relative correlation. Although the porosity and permeability has correlation, the permeability is tight, interpreted as the effect of intense cementation in this microfacies. 


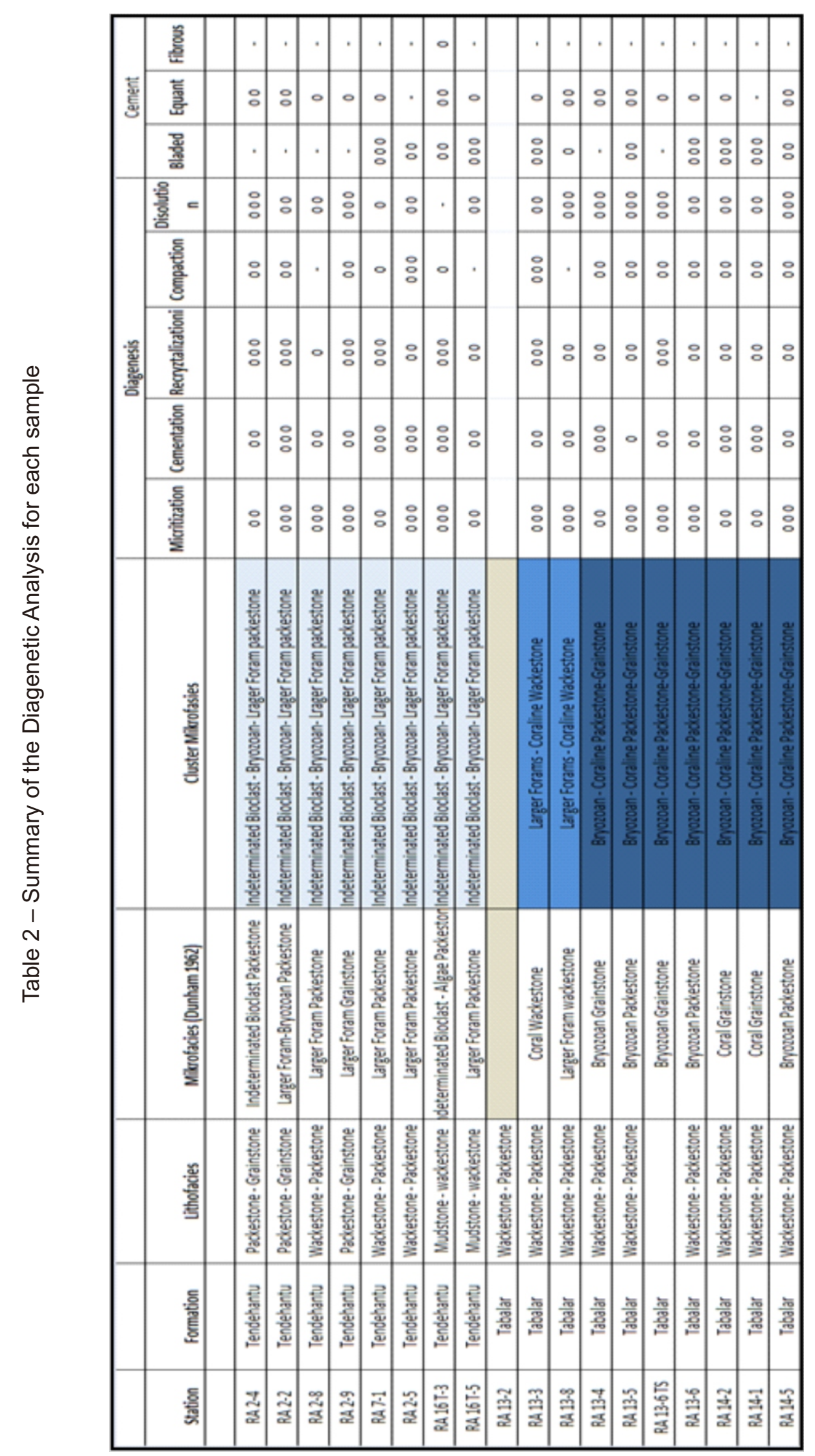




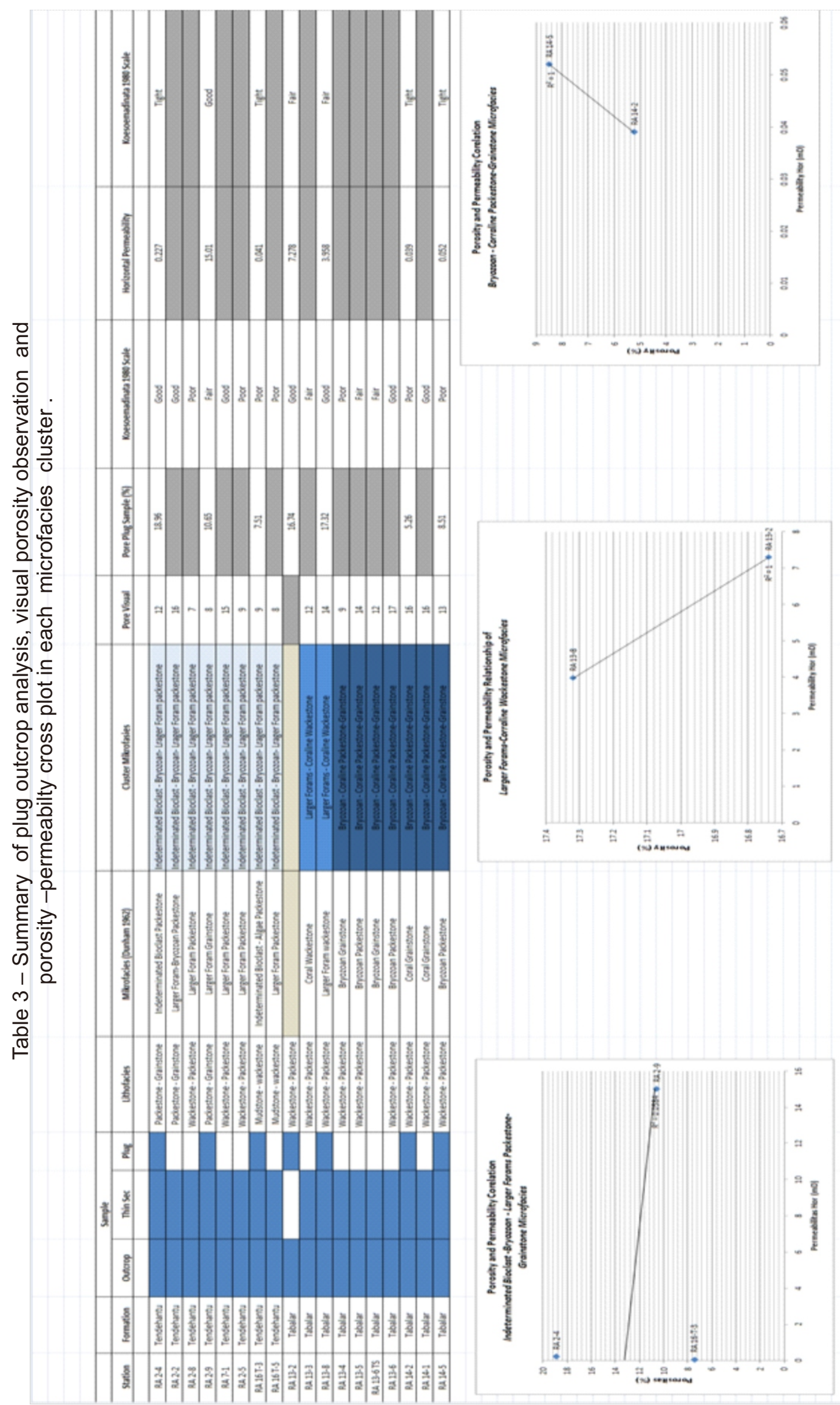


The porosity was reduced by the cementation. Based on that data the Bryozoan - Coraline Packestone Grainstone microfacies generally has fair quality as a reservoir candidate.

\section{CONCLUSION}

1. The Tabalar Formation based on field observation can be determined into one lithofacies, which is wackestone packestone. The Tendehantu Formation has two lithofacieses based on field observation. They are wackestone - packestone and packstone - grainstone lithofacieses.

2. Petrographical analysis divided the 3 lithofacieses into 3 lithofacies clusters. Those are; Indeterminated Bioclast - Bryozoan Larger Forams Packestone - Grainstone Microfacies, Larger Forams - Coraline Wackestone and Bryozoan - Coraline Packestone-Grainstone.

3. The complex diagenetic processes that happened in the two formations were microbial micritization, dissolution, cementation, and compaction, which happened in four stage.

4. The potential reservoir candidate is Indeterminated Bioclast - Bryozoan - Larger Forams Packestone - Grainstone Microfacies from Tendehantu Formation and Larger Forams - Coraline Wackestone from Tabalar Formation with good quality prediction.

\section{ACKNOWLEDGEMENTS}

We would like to thank Salamander Energy Ltd. for supporting and funding this research and GDA Consulting for the support during field work. Dr Ildrem Syafri, Mr.Ismawan, \& Mr Djadjang J. Setiadi are thanked for supervising this paper.

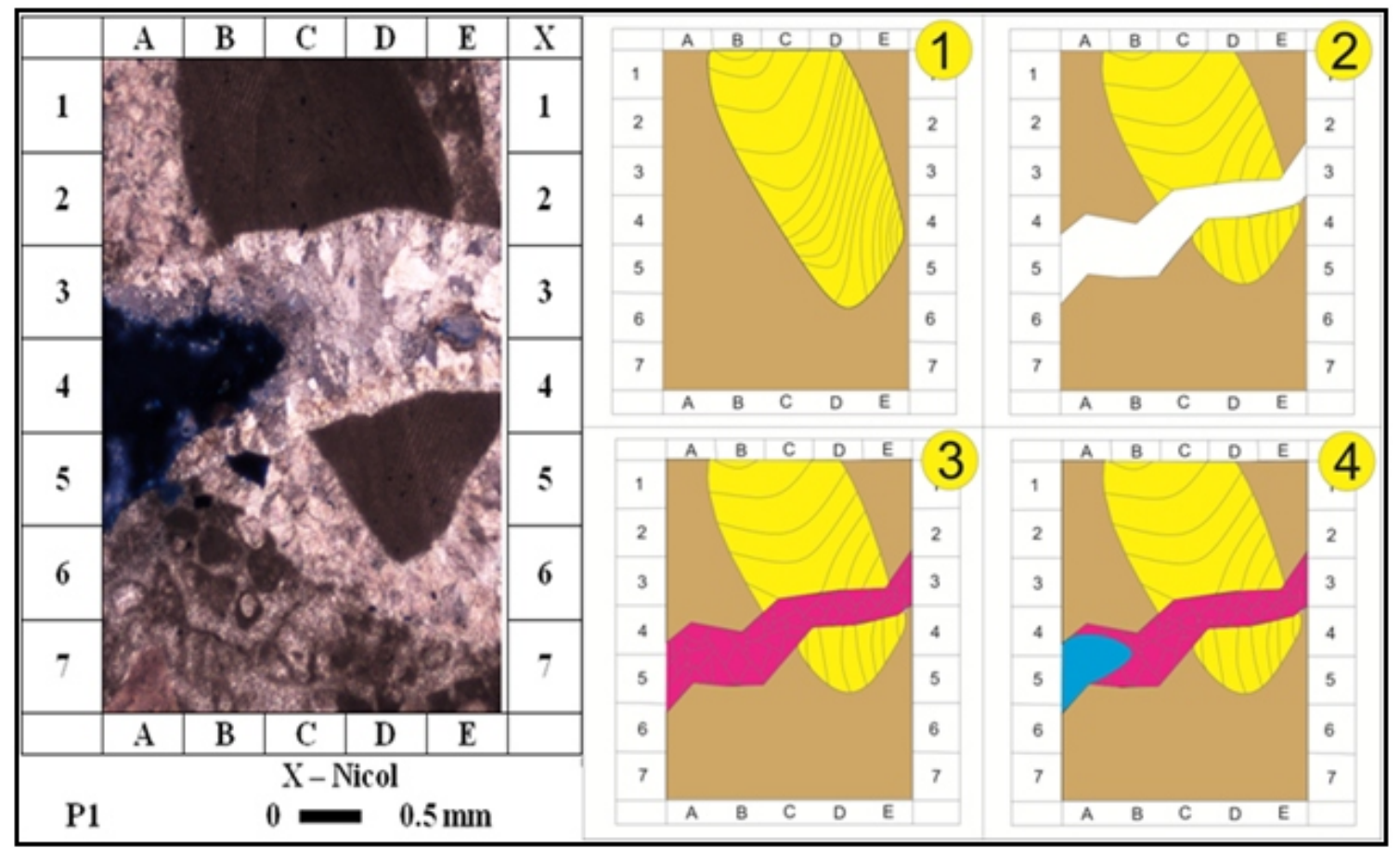

Figure 12 - RA 14-4 Thin section photograph and the diagenetic stage illustration.

(1) Microbial Micritization in red algae fragment possibly happened in marine phreatic. (2) Fracturing in algae fragment, possibly caused by burial regime. (3) Blocky and bladed cementation were developed in fracture possibly in meteoric phreatic regime, this phase reduce the fracture pores. (3) The latest diagenesis stages that recorded here is dissolution in cement that formed before, this phase possibly in meteoric vadose. 


\section{MAKALAH ILMIAH}

\section{REFERENCES}

Djamal, B., Sudana, D., Soetrisno, Baharuddin, and Hasan, K., 1995, Geological Map of the Tanjung Mangkalihat Sheet, Kalimantan: Geological Research and Development Centre, Bandung, Indonesia, Scale 1:250,000.

Koesoemadinata, R.P., 1980, GeologiMinyakdan Gas Bumi, EdisikeduaJilid I.Penerbit ITB, Bandung.

Longman, M. W., 1982, Carbonates Diagenesis as Control on Stratigraphy Traps; Fall Education Conference in Calgary, Canada.

Moore, C.H., 2004. Carbonate Reservoir : Porosity Evaluation and Diagenesis in A Sequence Stratigraphy Framework. Elsevier Science B.V. Amsterdam.

Satyana, A.H., 2003, Accretion and Dispersion of Southeast Sundaland : the Growing and Slivering of a Continent, Joint Convention of Indonesian Association of Geologists (IAGI), 31stAnnual Convention and Indonesian Association of Geophysicists (HAGI), 28thAnnual Convention, Jakarta, December 2003. 